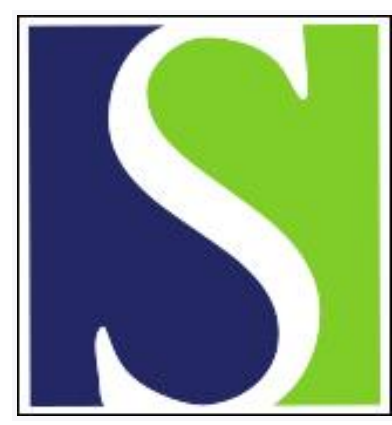

Scand J Work Environ Health 1992;18(4):209-215

https://doi.org/10.5271/sjweh.1578

Issue date: 01 Aug 1992

\title{
Clues to cancer etiology from studies of farmers.
}

by Blair A, Zahm SH, Pearce NE, Heineman EF, Fraumeni JF Jr

Affiliation: Epidemiology and Biostatistics Program, National Cancer Institute, Bethesda, Maryland 20892.

The following article refers to this text: 2016;42(2):144-152

This article in PubMed: www.ncbi.nlm.nih.gov/pubmed/1411362 


\title{
Clues to cancer etiology from studies of farmers
}

\author{
by Aaron Blair, PhD, ${ }^{1}$ Shelia Hoar Zahm, ScD, ${ }^{1}$ Neil E Pearce, PhD, ${ }^{2}$ \\ Ellen F Heineman, PhD, ${ }^{1}$ Joseph F Fraumeni Jr, MD ${ }^{1}$
}

\begin{abstract}
BLAIR A, HOAR ZAHM S, PEARCE NE, HEINEMAN EF, FRAUMENI JF Jr. Clues to cancer etiology from studies of farmers. Scand $J$ Work Environ Health 1992;18:209-15. This article summarizes cancer risks among farmers to clarify the magnitude of the problem and to suggest directions for future research. Significant excesses occurred for Hodgkin's disease, multiple myeloma, leukemia, skin melanomas, and cancers of the lip, stomach, and prostate. Nonsignificant increases in risk were also noted for non-Hodgkin's lymphoma and cancers of connective tissue and brain. These excesses occurred against a background of substantial deficits among farmers for total mortality and mortality from many specific diseases. The tumors vary in frequency, histology, and prognosis and do not fall into any obvious grouping. Two commonalities may be important. Several of the tumors excessive among farmers appear to be rising in the general population and are excessive among patients with naturally occurring or medically induced immunodeficiencies. Therefore epidemiologic studies on specific exposures among farmers may help explain the rising trend of certain cancers in developed countries and provide clues to mechanisms of action for environmental carcinogens.
\end{abstract}

Key terms: agriculture, immunology, pesticides, review.

Traumatic death and injury, respiratory disease, and dermatitis have long been recognized as special problems in agriculture (1). The advent of modern agriculture with its heavy reliance on chemicals has raised concerns about chronic diseases such as cancer (2-4). Epidemiologic investigations of farmers have suggested elevated incidence and mortality for certain cancers. The increasing opportunity for exposure among the general population to chemicals commonly encountered in agriculture suggests that studies of farmers may provide clues to environmental factors that may contribute to the rising rates for some tumors (5). In this paper we have assembled data on cancer risk among farmers to clarify the magnitude of the problem in agriculture and to suggest directions for future cancer research.

\section{Materials and methods}

Data from broad occupational surveys on cancer mortality or morbidity were assembled from several countries. We included published surveys which provided data on many occupations or many diseases or both to avoid the potential problem of a bias toward the

\footnotetext{
1 Epidemiology and Biostatistics Program, National Cancer Institute, Bethesda, Maryland, United States.

2 Wellington School of Medicine, Wellington, New Zealand.
}

Reprint requests to: Dr A Blair, National Cancer Institute, Executive Plaza North, Room 418, Bethesda, MD 20892, USA. reporting of positive findings. Specifically excluded were studies of individual cancers in which negative findings are likely to go unreported. In a meta-analysis we summed the observed and expected numbers for specific cancers, total mortality, and ischemic heart disease among farmers to create meta-relative risk (MRR) estimates to minimize the influence of unusual chance findings from individual studies on the overall interpretation. This procedure weights the contribution of each study by its size. Statistical significance was evaluated using $95 \%$ confidence intervals, which were calculated for the MRR estimates using the procedures for a Poisson variable by Breslow \& Day (6). We have also presented the range of relative risks observed among the studies, the number of studies with relative risks exceeding unity, the number of statistically significant excesses, the number of studies with relative risks less than unity, and the number with significant deficits to evaluate the distribution, magnitude, and consistency of the individual relative risks. This approach weights the contribution of each investigation equally. The statistical significance of the distribution of relative risks greater than and less than 1.00 was evaluated by a sign test (7). See figure 1 for a graphic presentation of the relative risks and $95 \%$ confidence intervals for selected cancers.

In analyses such as this it is desirable to be able to adjust for confounding and bias that may occur in the data sets used. Since we did not have access to the raw data, such an adjustment was not possible. It seems unlikely, however, that a common set of problems would exist in the various data sets, which were assembled in different ways and were from many different countries. 

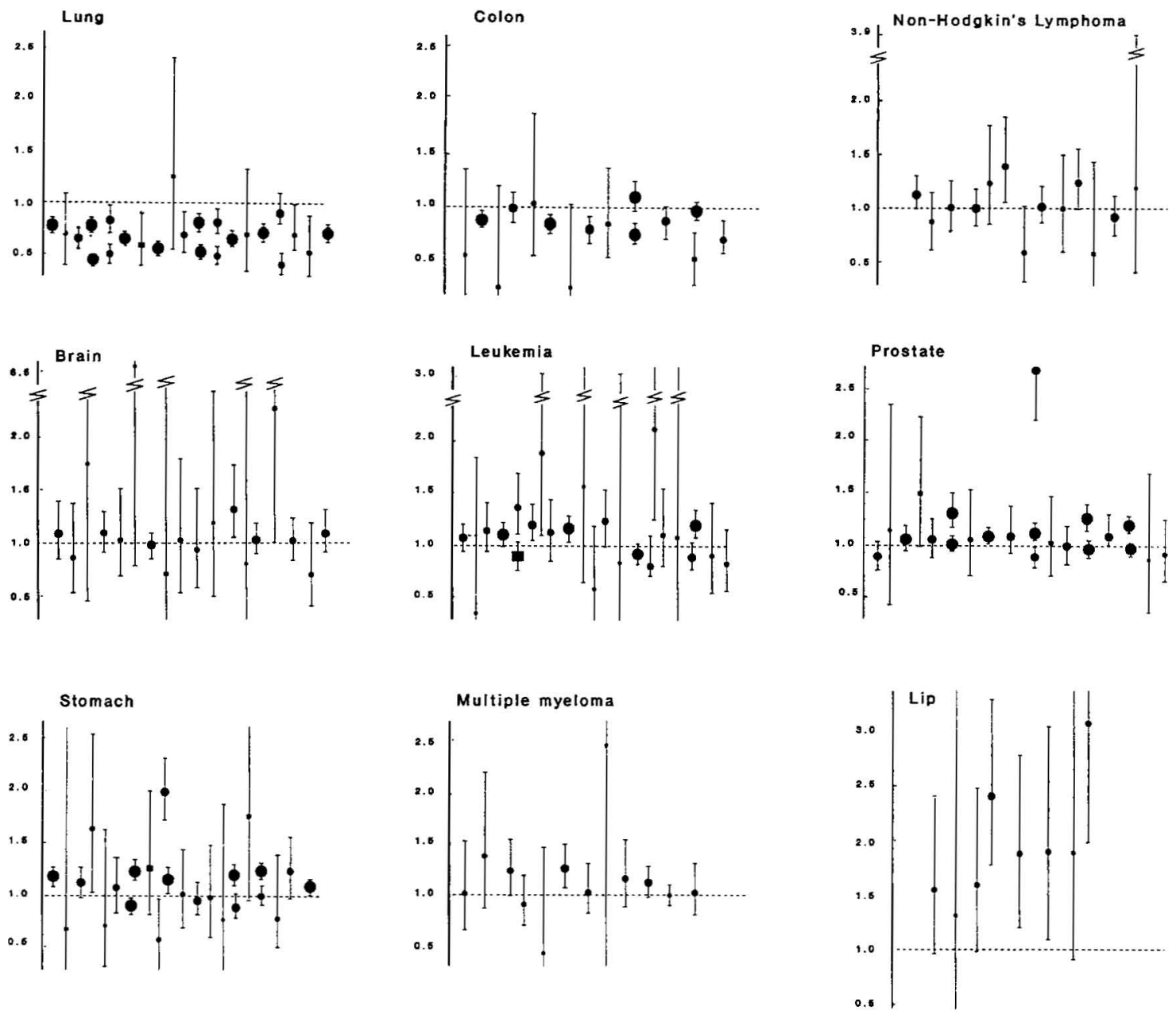

Legend

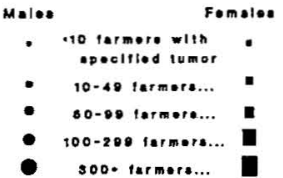

Figure 1. Relative risks and $95 \%$ confidence intervals for selected cancers by study. The vertical bars represent the $95 \%$ confidence intervals obtained from the papers, if available; otherwise they were calculated according to Breslow \& Day (6).

\section{Results}

Table 1 displays summary data from studies specifically on farmers and from surveys that included evaluations of many occupations in addition to farmers. In these studies, mortality among farmers was usually compared with the risk in the general population. Statistically significant deficits in the MRR estimates occurred for all causes combined, ischemic heart disease, and all cancer combined. For these disease categories, the relative risks were less than 1.0 in nearly every study, most being statistically significant. Significant deficits among farmers occurred for cancers of the lung, esophagus, bladder, colon, liver, and kidney. Few individual studies had relative risks greater than 1.0 for these tumors. MRR estimates significantly greater than 1.0 were obtained for Hodgkin's disease, melanoma, multiple myeloma, leukemia, and cancers of the lip, stomach and prostate. The excesses, however, were small, and some individual studies showed deficits. Although the MRR estimates for non-Hodgkin's lymphoma and cancers of the connective tissue and brain were not significantly elevated, more individual studies of farmers showed excesses of these cancers than deficits.

Two studies $(27,28)$ included in table 1 evaluated cancer risks among female farmers, but the small numbers observed complicated comparison with the pattern among male farmers. Although the female farmers presumedly operated or worked on farms, no information was available to compare the type of farming performed by women with the type performed by men. Among the women only, for selected sites with at least 10 deaths, the MRR estimates were 1.23 (19 
observed and 15.4 expected deaths) for stomach cancer, 0.76 (11 observed, 14.5 expected) for bladder cancer, 1.05 (17 observed, 16.2 expected) for melanoma, 0.81 (37 observed, 45.7 expected) for other skin cancer, 0.70 (31 observed, 44.3 expected) for lung cancer, 0.89 (175 observed, 195.6 expected) for leukemia, 1.02 (163 observed, 160.5 expected) for breast cancer, and 1.05 (160 observed, 152.5 expected) for other genital cancer.

\section{Discussion}

Although farmers comprise one of the largest occupational groups with exposures to potentially hazardous substances, agriculture has not been a high priority on the occupational health research agenda (1). Issues of exposure and health in agriculture have typically fallen through the cracks of governmental systems in the United States (29) and other countries, since work per-

Table 1. Summary of risks for cancer and other causes of death among farmers (8-28).

\begin{tabular}{|c|c|c|c|c|c|c|c|c|}
\hline $\begin{array}{l}\text { Disease and } \\
\text { references }\end{array}$ & $\begin{array}{c}\text { Total } \\
\text { diseased }\end{array}$ & $\begin{array}{l}\text { Meta } \\
\text { relative } \\
\text { risk }\end{array}$ & $\begin{array}{l}95 \% \\
\text { confidence } \\
\text { interval for } \\
\text { the meta } \\
\text { relative } \\
\text { risk }\end{array}$ & $\begin{array}{l}\text { Range of } \\
\text { relative } \\
\text { risks }\end{array}$ & $\begin{array}{l}\text { Number } \\
\text { of } \\
\text { studies }\end{array}$ & $\begin{array}{l}\text { Number of } \\
\text { relative } \\
\text { risks } \\
<1.0 / \\
\text { number of } \\
\text { relative } \\
\text { risks } \\
\text { significant } \\
<1.0\end{array}$ & $\begin{array}{l}\text { Number of } \\
\text { relative } \\
\text { risks } \\
>1.0 / \\
\text { number of } \\
\text { relative } \\
\text { risks } \\
\text { significant } \\
>1.0\end{array}$ & $\begin{array}{l}X^{2} \\
\text { from } \\
\text { Sign } \\
\text { test }\end{array}$ \\
\hline $\begin{array}{l}\text { Ischemic heart disease } \\
(12,13,16,17,19,20,22 \text {, } \\
24,25,27,28)\end{array}$ & 65898 & 0.89 & $0.88-0.90$ & $0.6-1.1$ & 12 & $8 / 6$ & $2 / 0$ & $3.00^{\mathrm{c}}$ \\
\hline $\begin{array}{l}\text { All cancer }(9,11-17 \\
19-25,27,28)\end{array}$ & 47593 & 0.89 & $0.88-0.90$ & $0.6-1.0$ & 20 & $18 / 13$ & $0 / 0$ & $15.3^{\mathrm{a}}$ \\
\hline Lung $(8-14,16-28)$ & 8018 & 0.66 & $0.64-0.67$ & $0.4-1.3$ & 24 & $23 / 19$ & $1 / 0$ & $20.2^{\mathrm{a}}$ \\
\hline $\begin{array}{l}\text { Esophagus }(8-12,14,16 \\
18-20,22-28)\end{array}$ & 777 & 0.74 & $0.69-0.80$ & $0.5-1.7$ & 18 & $12 / 7$ & $5 / 0$ & 2.72 \\
\hline $\begin{array}{l}\text { Bladder }(8-13,16-24 \text {, } \\
26-28)\end{array}$ & 1948 & 0.85 & $0.81-0.89$ & $0.5-1.1$ & 21 & $19 / 5$ & $2 / 0$ & $13.8^{a}$ \\
\hline $\begin{array}{l}\text { Colon }(8,12,14 \\
16-24,26,27)\end{array}$ & 2952 & 0.87 & $0.84-0.90$ & $0.3-1.1$ & 15 & $13 / 6$ & $2 / 0$ & $8.07^{a}$ \\
\hline $\begin{array}{l}\text { Liver }(8,9,16,18-20 \\
22-24,27,28)\end{array}$ & 510 & 0.89 & $0.81-0.97$ & $0.5-2.0$ & 13 & $7 / 1$ & $6 / 0$ & 0.08 \\
\hline $\begin{array}{l}\text { Kidney }(8-10,13,17,19 \\
20,22-24,26-28)\end{array}$ & 965 & 0.92 & $0.86-0.98$ & $0.6-1.5$ & 15 & $9 / 3$ & $6 / 0$ & 0.60 \\
\hline $\begin{array}{l}\text { Testis }(8-10,16,18-20 \\
22,26-28)\end{array}$ & 161 & 0.88 & $0.79-1.03$ & $0.6-1.4$ & 10 & $5 / 1$ & $5 / 0$ & 0.03 \\
\hline $\begin{array}{l}\text { Nose }(8,10,16,22,23 \text {, } \\
27,28)\end{array}$ & 53 & 0.94 & $0.70-1.23$ & $0.6-2.4$ & 8 & $4 / 0$ & $4 / 0$ & 0.03 \\
\hline $\begin{array}{l}\text { Pancreas }(8-12,14, \\
16-20,22-28)\end{array}$ & 2415 & 0.98 & $0.94-1.02$ & $0.5-1.6$ & 20 & $11 / 2$ & $9 / 0$ & 0.20 \\
\hline $\begin{array}{l}\text { Rectum }(8,14,16-20 \\
22-24,26,27)\end{array}$ & 1512 & 1.00 & $0.95-1.05$ & $0.8-1.7$ & 13 & $6 / 1$ & $7 / 1$ & 0.08 \\
\hline Breast (female) $(27,28)$ & 163 & 1.02 & $0.87-1.18$ & $1.0-1.2$ & 2 & $0 / 0$ & $2 / 0$ & 1.13 \\
\hline $\begin{array}{l}\text { Skin other than } \\
\text { melanoma }(10,11,16 \text {, } \\
22,23,27,28)\end{array}$ & 348 & 1.04 & $0.93-1.16$ & $0.7-1.7$ & 8 & $4 / 0$ & $4 / 3$ & 0.03 \\
\hline $\begin{array}{l}\text { Female genital organs } \\
(27,28)\end{array}$ & 160 & 1.05 & $0.89-1.22$ & $0.9-1.1$ & 2 & $1 / 0$ & $1 / 0$ & 0.13 \\
\hline $\begin{array}{l}\text { Non-Hodgkin's lymphoma } \\
(8,9,11,12,16,18,21 \\
22,25,27,28)\end{array}$ & 911 & 1.05 & $0.98-1.12$ & $0.6-1.4$ & 14 & $5 / 0$ & $8 / 1$ & 0.64 \\
\hline $\begin{array}{l}\text { Brain }(8-11,13,14 \\
16-22,24,25,27)\end{array}$ & 979 & 1.05 & $0.99-1.12$ & $0.7-6.5$ & 18 & $5 / 0$ & $13 / 2$ & $3.56^{c}$ \\
\hline $\begin{array}{l}\text { Connective tissue } \\
(8,9,16,18,22,25,27)\end{array}$ & 159 & 1.06 & $0.91-1.24$ & $0.9-1.5$ & 7 & $2 / 0$ & $5 / 0$ & 1.29 \\
\hline $\begin{array}{l}\text { Leukemia }(8-14,16-22 \text {, } \\
24-28)\end{array}$ & 2625 & 1.07 & $1.03-1.11$ & $0.3-2.4$ & 23 & $9 / 0$ & $14 / 6$ & 1.09 \\
\hline Prostate $(8-14,16-28)$ & 7753 & 1.08 & $1.06-1.11$ & $0.9-2.7$ & 22 & $6 / 1$ & $15 / 6$ & $3.68^{c}$ \\
\hline Stomach $(8-14,16-28)$ & 7182 & 1.12 & $1.09-1.14$ & $0.6-2.0$ & 24 & $9 / 2$ & $14 / 8$ & 1.04 \\
\hline $\begin{array}{l}\text { Multiple myeloma } \\
(8-12,16,18,22,25-27)\end{array}$ & 694 & 1.12 & $1.04-1.21$ & $0.4-2.5$ & 12 & $2 / 0$ & $9 / 1$ & $4.08^{b}$ \\
\hline $\begin{array}{l}\text { Melanoma }(8,10,11,16 \\
18,21,22,27,28)\end{array}$ & 374 & 1.15 & $1.04-1.28$ & $0.5-6.3$ & 11 & $2 / 0$ & $9 / 3$ & $4.45^{b}$ \\
\hline $\begin{array}{l}\text { Hodgkin's disease }(8,9 \text {, } \\
11,16-20,22,27,28)\end{array}$ & 325 & 1.16 & $1.03-1.29$ & $0.9-4.1$ & 12 & $2 / 0$ & $10 / 2$ & $5.53^{b}$ \\
\hline $\begin{array}{l}\operatorname{Lip}(8,9,12,16,18,22 \\
23,27)\end{array}$ & 188 & 2.08 & $1.80-2.40$ & $1.3-3.1$ & 8 & $0 / 0$ & $8 / 4$ & $7.03^{a}$ \\
\hline $\begin{array}{l}\text { Total mortality }(13-15 \text {, } \\
17,21,22,24,25,28)\end{array}$ & 106051 & 0.86 & $0.86-0.87$ & $0.6-1.9$ & 10 & $9 / 9$ & $1 / 1$ & $6.40^{\mathrm{b}}$ \\
\hline
\end{tabular}

a $\mathrm{P}<0.01$, b $\mathrm{P}<0.05$, c $\mathrm{P}<0.10$. 
formed by family members is typically not affected by state or federal labor regulations (30). A more intensive focus on agriculture is needed to ensure that farmers have the same protection that is generally provided to other occupational groups. Epidemiologic investigations are important to preventive efforts, as they can provide new leads to the etiology of tumors excessive among farmers.

The mortality experience of farmers is favorable in terms of all causes, all cancers combined, and ischemic heart disease. The low rates for cancers of the lung, esophagus, and bladder, as well as heart disease, may be explained by the low prevalence of smoking observed globally among farmers $(15,24,31-34)$. In addition, the physical demands on farmers may account for their low body fat and high levels of physical fitness (35), which in turn may contribute to lower risks for heart disease and colon cancer (35-40). Dietary factors (such as high intake of fresh fruits and vegetables), residence in areas with little air pollution, and selective migration may influence the deficits of cancer observed, but these factors have not been evaluated among farmers.

In contrast to the deficits for most major disease categories, farmers had significantly elevated risks for leukemia, multiple myeloma, Hodgkin's disease, melanoma, and cancers of the lip, prostate and stomach. Mortality from non-Hodgkin's lymphoma and cancers of connective tissue and brain was increased in most studies, although the MRR estimates were not significant. These tumors do not fall into an obvious grouping, other than the fact that they are not strongly associated with smoking. They vary in frequency, histology, and prognosis. The excesses among farmers for a few specific cancers, against a background of low risks for most cancers and nonneoplastic disease, suggest a role for work-related exposures. These patterns may have broader public health implications, since several of the high-rate tumors among farmers also appear to be increasing in the general population of many developed countries (5). Of particular interest are the rising rates for multiple myeloma, non-Hodgkin's lymphoma, melanoma, and cancer of the brain. Prostate cancer has increased especially in England and Wales (41) and the United States (42). Some of these trends may partially result from improvements in diagnosis and reporting, which affect incidence rates to a greater extent than mortality statistics (42). However, it is noteworthy that, in the United States, the rising mortality rates for non-Hodgkin's lymphoma, multiple myeloma, and leukemia have been the most pronounced in rural agricultural areas of the central region of the country (43). Although stomach cancer has been declining in all developed countries, the rates for tumors arising in the gastric cardia have increased remarkably for unknown reasons $(44,45)$.

For cancers showing excess risks among farmers, the MRR estimates are not large. It is perhaps not surprising that the relative risks from these summary mea- sures were small because the broad occupational category of farmer was all that was available for these analyses. Since not all farmers have the same exposures, combining those with different exposures would tend to dilute the effects of relevant exposures and bias risk estimates toward the null (46). The potential magnitude of such a dilution effect can be illustrated with data from a recent study in lowa and Minnesota (47). Among the 698 population-based referents who ever lived on farms, $110(16 \%)$ never used insecticides and $344(49 \%)$ never used herbicides. The proportion of farmers who used specific classes of pesticides was even smaller. Approximately $40 \%$ of the farmers used phenoxy acid herbicides and $20 \%$ used organochlorine insecticides, the two most frequently used pesticide classes. Even if these chemicals were strong risk factors for a particular cancer, analyses based simply on the occupational title of farmer could seriously underestimate the relative risks. For example, if the $40 \%$ of the farmers who used phenoxy acid herbicides had twice the risk of some disease as nonusing farmers, an analysis that considered all farmers exposed would yield a relative risk of 1.4 . If only $20 \%$ of the farmers used the hazardous substance of interest (eg, organochlorine insecticides), the relative risk for farmers would be 1.2. These examples represent classes of chemicals, so the dilution effect would be more dramatic for specific chemical agents. Classifying farmers by specific exposures is clearly preferable, but such a classification was not available from the surveys included in this review.

To overcome this bias, future studies of farmers should focus on carcinogenic risks from specific exposures, including pesticides, fertilizers, fuels and engine exhausts, organic and inorganic dusts, solvents, ultraviolet light, and zoonotic viruses. Such studies may provide explanations for the rising incidence of certain cancers $(5,42)$ and the carcinogenic potential of environmental agents that are much more difficult to evaluate in the general population.

Several etiologic clues to farming-related cancer already exist. Because of the outdoor nature of their work, farmers may have considerable exposure to ultraviolet light, a strong risk factor for melanoma and cancer of the lip (48). Exposure to pesticides, particularly phenoxy acid herbicides, has been linked to nonHodgkin's lymphoma (49-53) and soft-tissue sarcoma (54-57), although risk estimates vary widely among studies and in some the risk was not increased at all (3). Insecticides have been associated with leukemia $(47,58)$, multiple myeloma $(59,60)$, and brain cancer (61). While the use of fertilizers has not been evaluated in relation to cancer risk among farmers, nitrates have been related to stomach cancer in some epidemiologic and experimental investigations (62). The growing contamination of drinking water sources with nitrates in agricultural areas (63) makes this an issue of special concern. In addition, a study of Canadian farmers reported an association between non- 
Hodgkin's lymphoma and expenditures on fuels and oils, which may reflect exposure to these substances or to engine exhausts (25). A role for fumigants and organic dusts is suggested by the elevated risks of nonHodgkin's lymphoma among grain handlers in the United States (64) and stomach cancer among grain farmers in China (65). Farmers may also come into contact with animals infected with oncogenic viruses. Excesses of acute lymphocytic leukemia were reported among farmers residing in Iowa counties where dairy herds were infected with the bovine leukemia virus (66), but there is no serologic evidence suggesting transmission to humans $(67,68)$. However, other oncogenic viruses are prevalent in farm animals, and excess risks of soft-tissue sarcoma, non-Hodgkin's lymphoma, and leukemia have been observed among slaughterhouse workers (3) and veterinarians (2). These occupations are interesting because of the frequent contact with animals and animal products, but only limited exposure to agricultural chemicals.

Although agricultural pesticides have been linked to certain cancers, the mechanisms of action are obscure. Some pesticides are genotoxic. In an evaluation of genetic damage from 65 pesticides in 14 in vivo and in vitro tests, nine were active in most tests, 26 were active in several tests, and 30 were inactive in all tests (69). Some pesticides may operate through epigenetic pathways, including the immune system. In experimental studies, pesticides have caused a variety of immune defects including decreased host resistance to infection, thymus atrophy, suppressed T-cell activity, enhanced B- and T-cell immune response, and contact hypersensitivity (70). Newcombe (71) recently proposed that organophosphates may play a role in oncogenesis through their inhibition of serine esterases, which are critical components in the cytolytic activities of $\mathrm{T}$ lymphocytes and natural killer cells.

Although only limited data are available on immune alterations from human pesticide exposure (70), it is well documented that patients with naturally occurring or medically induced immunodeficiencies experience striking excesses of non-Hodgkin's lymphoma (72-77). In addition, leukemia and stomach cancer appear to be excessive among persons with primary immunodeficiency syndromes; soft-tissue sarcomas, melanoma, and squamous carcinomas of the skin and lip occur in renal transplant recipients $(75,76)$; and brain and skin cancers occur among bone-marrow transplant recipients (77). Since several of the tumors seen in immunocompromised subjects, including nonHodgkin's lymphoma, appear to be excessive among farmers, it is possible that agricultural exposures affect cancer risks through immunologic perturbations that remain to be identified.

Clues to carcinogenic exposures among farmers have come primarily from case-referent interview studies involving soft-tissue sarcomas and cancers of the lymphatic and hematopoietic system. Because they are typically independent operators, farmers are able to provide considerable detail about their work practices and chemical exposures so that case-referent studies appear well-suited for evaluating cancers (eg, stomach, brain, and prostate) that have received little attention. The infrequent use and the changing patterns of the use of agricultural chemicals suggest, however, the utility of prospective studies as well. By incorporating environmental and biologic measures with detailed interview data, prospective studies could improve precision in exposure assessment, identify early markers for disease, eliminate the possibility of case-recall bias, and help to develop and evaluate preventive approaches. Such studies would need to be very large, however, because the cancers of interest are rare. Once established, however, the study population could also be used to investigate outcomes other than cancer, such as neurotoxicity, immunotoxicity, and birth or developmental defects, which are also of concern from pesticide exposure (78). In the United States, the National Cancer Institute, in collaboration with the Environmental Protection Agency and the National Institute for Environmental Health Sciences, is undertaking such a prospective study.

Most epidemiologic studies to date have focused on male operators of family farms. More attention should be given to migrant workers and farm laborers, who may experience greater exposures to some chemicals than owners or operators. Furthermore, studies in tropical countries would be useful because of climatic conditions that result in heavier use of pesticides than in temperate areas. More data are also needed on cancer risks among women who are farmers and spouses of farmers. Exposures among spouses and other dependents who are not directly engaged in farm work, although lower than among farmers and farm workers, may be greater than exposures among the general population. Studies that include dependents with indirect exposures could provide insights into risks the general public may face.

In summary, despite low risks for most major causes of death, farmers tend to be at higher risk for cancers of the lip, melanoma, brain, prostate, stomach, connective tissue, and lymphatic and hematopoietic system than the general population. The incidence and mortality rates for many of these tumors are increasing in the general population of developed countries, although there is much controversy about the relative impact of diagnostic and reporting changes versus environmental hazards on the upward trends $(5,79)$. Several aspects of our analysis limit interpretation. We combined results from studies from several countries that may differ regarding the time period covered, type of agriculture practiced (which would result in different exposures), comparison population used, and ethnic and sociodemographic characteristics of the populations surveyed. These differences undoubtedly introduce "noise" into the summary risk estimates, and they would tend to obscure real patterns. On the other hand, because 26 outcomes were considered, chance 
effects cannot be entirely ruled out for some of the MRR estimates. However, the MRR estimates were significantly less than $\mathbf{1 . 0}$ for nine causes of death and significantly elevated for seven, far more than would be expected from chance. Consistency of the findings across the various studies provides some protection against purely chance results. Despite these limitations the data suggest that farmers experience excesses for certain tumors. Analytic studies aimed at detecting carcinogenic exposures in the agricultural setting are needed to provide clues as to which factors may contribute to these excesses. Such investigations may also identify environmental factors which may contribute to rising incidence rates for corresponding tumors in the general population.

\section{References}

1. Merchant JA, Kross BC, Donham KJ, Pratt DS, ed. Agriculture at risk - a report to the Nation. Iowa City, IA: Institute of Agricultural Medicine and Occupational Health, University of Iowa, 1989.

2. Blair A, Malker H, Cantor KP, Burmeister L, Wiklund K. Cancer among farmers: a review. Scand J Work Environ Health 1985;11:397—407.

3. Pearce N, Reif JS. Epidemiologic studies of cancer in agricultural workers. Am J Ind Med 1990;18:133-42.

4. Blair A, Zahm SH. Cancer among farmers. In: Cordes DH, Rea DF, ed. Health hazards of farming. Phildelphia, PA: Hanely and Belfus, Inc, 1991:335-54.

5. Davis DL, Hoel D, Fox J, Lopez A. International trends in cancer mortality in France, West Germany, Italy, Japan, England and Wales, and the USA. Lancet 1990; 336:474-81.

6. Breslow NE, Day NE. Statistical methods in cancer research; vol II (The design and analysis of cohort studies). Lyon: International Agency for Research on Cancer, 1987. (IARC scientific publications; no 82.)

7. Armitage P. Statistical methods in medical research London: Blackwell Scientific Publications, 1973.

8. Brownson RC, Reif JS, Chang JC, Chang JC. Cancer risks among Missouri farmers. Cancer 1989;64:2381-6.

9. Burmeister LF. Cancer mortality in Iowa farmers, 1971-1978. J Natl Cancer Inst 1981;66:461-4.

10. Decoufle P, Stanislawizyk K, Houten L, Bross IDJ, Viadana $E$. A retrospective survey of cancer in relation to occupation. Cincinnati, $\mathrm{OH}$ : National Institute for Occupational Safety and Health, 1977. (DHEW (NIOSH) publ no 77-178.)

11. Delzell E, Grufferman S. Mortality among white and nonwhite farmers in North Carolina, 1976-1978. Am J Epidemiol 1985;121:391-402.

12. Gallagher RP, Threlfall WJ, Jeffries E, Band PR, Spinelli J, Coldman AJ. Cancer and aplastic anemia in British Columbia farmers. J Natl Cancer Inst 1984;72: $1311-5$.

13. Guralnick L. Mortality by occupation and cause of death. Washington, DC: Department of Health Education and Welfare, 1963. (DHEW (vital statistics special rep no 53(3).)

14. Howe GR, Lindsay JP. A follow-up study of a tenpercent sample of the Canadian labor force: I. cancer mortality in males, 1965-1973. J Natl Cancer Inst 1983; 70:37-44.

15. Notkola VJ, Husman KRH, Laukkanen VJ. Mortality among male farmers in Finland during 1979-1983. Scand J Work Environ Health 1987;13:124-8.

16. Petersen GR, Milham S Jr. Occupational mortality in the state of California, 1959-1961. Rockville, MD: National Institute for Occupational Safety and Health, 1980. (DHEW (NIOSH, NIH) publ no 80-104, 1980.)

17. Rafnsson V, Gunnarsdottir H. Mortality among farmers in Iceland. Int J Epidemiol 1989;18:146-51.

18. Reif J, Pearce N, Fraser J. Cancer risks in New Zealand farmers. Int J Epidemiol 1989;18:768-74.

19. Saftlas AF, Blair A, Cantor KP, Hanrahan L, Anderson HA. Cancer and other causes of death among Wisconsin farmers. Am J Ind Med 1987;11:119-29.

20. Schwartz E, Grady K. Patterns of occupational mortality in New Hampshire, 1975-1985. Concord, NH: New Hampshire Division of Public Health Services, 1986.

21. Stark AD, Chang H, Fitzgerald EF, Riccardi K, Stone RR. A retrospective cohort study of mortality among New York state farm bureau members. Arch Environ Health 1987;42:204-12.

22. Statistics Sweden. Dodsfalls registret 1961-1970. Stockholm: Statistics Sweden, 1981.

23. Verluys $\mathbf{J J}$ : Cancer and occupation in The Netherlands. Br J Cancer 1949;3:162-85.

24. Walrath J, Rogot E, Murray J, Blair A. Mortality patterns among US veterans by occupation and smoking status. Washington DC: US Government Printing Office, 1985. (NIH publ no 85-2756.)

25. Wigle DT, Semenciw RM, Wilkins K, Riedel D, Ritter L, Morrison HI, et al. Mortality study of Canadian male farm operators: non-Hodgkin's lymphoma mortality and agricultural practices in Saskatchewan. J Natl Cancer Inst 1990;82:575-82.

26. Williams RR, Stegens NL, Goldsmith JR. Associations of cancer site and type with occupation and industry from the Third National Cancer Survey Interview. J Natl Cancer Inst 1977;59:1147-85.

27. Milham S Jr. Occupational mortality in Washington state, 1950-1979. Cincinnati, OH: National Institute for Occupational Safety and Health, 1983. (DHHS (NIOSH) Fubl no 83-116.)

28. Olsen J, Jensen OM. Occupation and risk of cancer in Denmark: an analysis of 93810 cancer cases, 19701979. Scand J Work Environ Health $1987 ; 13$ suppl 1: $1-91$.

29. Emanuel DA, Draves DL, Nycz GR. Occupational health services for farmers. Am J Ind Med 1990;18: $149-62$.

30. US Department of Labor. Child labor requirements in agriculture, United States, 1984, Fair Labor Standards Act. Child labor bulletin no 102; WH publication no 1295, 1984.

31. McMichael AJ, Hartshorne JM. Mortality risks in Australian men by occupational groups, 1968-1978. Med J Austr 1982;1:253-6.

32. Cassel J, Heyden S, Bartel AG, Kaplan BH, Tyroler HA, Cornoni JC, et al. Occupation and physical acitivity and coronary heart disease. Arch Intern Med 1971;128: $920-8$.

33. Central Bureau of Statistics. Smoking habits in Sweden: a mail survey - spring, 1963. Stockholm: Central Bureau of Statistics, 1965.

34. Surgeon General. Smoking and health - a report of the Surgeon General. Washington, DC: Department of Health, Education, and Welfare, 1979. (DHEW publ no (PHS) 79-50066), USGPO.)

35. Pfeiffer S, Graham TE, Webb RDG, Wilson BA, Rivington-Moss EG, Fisher-Ingram LM. Aspects of physical fitness and health in Ontario dairy farmers. Can J Public Health 1984;75:204-11.

36. Garabrant DH, Peters JM, Mack TM, Bernstein L. Job activity and colon cancer risk. Am J Epidemiol 1984; 119:1005-14.

37. Vena JE, Graham S, Zielezny M. Lifetime occupational exercise and colon cancer. Am J Epidemiol 1986;123: 
$775-80$.

38. Albanes D, Blair A, Taylor P. Physical activity and risk of cancer in the NHANES I population. Am J Public Health 1989;79:744-50.

39. Blair SN, Kohl HW, Paffenbarger RS, Clark DG, Cooper KH, Gibbons LW. Physical fitness and all-cause mortality: a prospective study of healthy men and women. J Am Med Assoc 1989;262:2395-401.

40. Brownson RC, Zahm SH, Chang JC, Blair A. Occupational risk of colon cancer - an analysis by anatomic subsite. Am J Epidemiol 1989;130:675-87.

41. Office of Census and Population Surveys. Reviews of the National Cancer Registration System (series MBI, no 17). London: HM Stationery Office, 1990.

42. Devesa SS, Silverman DT, Young JL, Pollack ES, Brown CC, Horm JW, et al. Cancer incidence and mortality trends among whites in the United States, 194784. J Natl Cancer Inst 1987;79:701-70.

43. Pickle LW, Mason TJ, Howard N, Hoover RN, Fraumeni JF Jr. Atlas of US cancer mortality among whites: 1950 - 1980. Washington, DC: US Government Printing Office, 1987. (DHHS publ no (NIH) 87-2900.)

44. Powell J, McConkey CC. Increasing incidence of adenocarcinoma of the gastric cardia and adjacent sites. Br J Cancer 1990;62:440-3.

45. Blot WJ, Devesa SS, Kneller RW, Fraumeni JF Jr. Rising incidence of adenocarcinoma of the esophagus and gastric cardia. JAMA 1991;265:1287-9.

46. Checkoway H, Pearce N, Crawford-Brown DJ. Research methods in occupational epidemiology. New York, NY: Oxford University Press, 1989.

47. Brown LM, Blair A, Gibson R, Everett GD, Cantor KP, Schuman LM, et al. Pesticide exposures and other agricultural risk factors for leukemia among men in Iowa and Minnesota. Cancer Res 1990;50:6585-91.

48. Lee JAH, Strickland D. Malignant melanoma: social status and outdoor work. Br J Cancer 1980;41:757-63.

49. Hardell L, Eriksson M, Lenner P, Lundgren E. Malig nant lymphoma and exposure to chemicals, especially organic solvents, chlorophenols, and phenoxy acids: a case-control study. Br J Cancer 1981;43:169-76.

50. Hoar SK, Blair A, Holmes FF, Holmes FF, Boysen CD, Robel RJ, et al. Agricultural herbicide use and risk of lymphoma and soft-tissue sarcoma. JAMA 1986;256: $1141-7$.

51. Persson B, Dahlander A, Fredriksson M, Brage HN, Ohlson CG, Axelson O. Malignant lymphoma and occupational exposures. Br J Ind Med 1989;46:516-20.

52. Zahm SH, Weisenburger DD, Babbitt PA, Saal RC, Vaught JB, Cantor KP, et al. A case-control study of non-Hodgkin's lymphoma and the herbicide 2,4-dichlorophenoxyacetic acid (2,4-D) in eastern Nebraska. Epidemiology 1990;1:349-56.

53. Woods JS, Polissar L, Severson RK, Heuser LS, Kulander BG. Soft tissue sarcoma and non-Hodgkin's lymphoma in relation to phenoxyherbicide and chlorinated phenol exposure in western Washington. J Natl Cancer Inst 1987;78:899-910.

54. Hardell L, Sandstrom A. Case-control study: soft-tissue sarcoma and exposure to phenoxyacetic acids and chlorophenols. Br J Cancer 1979;39:711-7.

55. Eriksson M, Hardell L, Berg NO, Moller T, Axelson $O$. Soft-tissue sarcomas and exposure to chemical substances: a case-referent study. Br J Ind Med 1981;38: 27-33.

56. Hardell L, Eriksson M. The association between soft tissue sarcomas and exposure to phenoxyacetic acids: a new case-referent study. Cancer 1988;62:652-6.

57. Vineis P, Terracini B, Ciccone G, Cignetti A, Colombo E, Donna A, et al. Phenoxy herbicides and soft-tissue sarcomas in female rice weeders: a population-based case-referent study. Scand J Work Environ Health 1987; 13:9-17.
58. Flodin U, Fredriksson M, Persson B, Axelson O. Chronic lymphatic leukaemia and engine exhausts, fresh wood, and DDT: a case-referent study. Br J Ind Med 1988;45:33-8.

59. Cantor KP, Blair A. Farming and mortality from multiple myeloma: a case-control study with the use of death certificates. J Natl Cancer Inst 1984;72:251-5.

60. Boffetta P, Stellman SD, Garfinkel L. A case-control study of multiple myeloma nested in the American Cancer Society prospective study. Int J Cancer 1989;43: 554-9.

61. Musicco M, Sant M, Molinari S, Filippini G, Gatta G, Berrino F. A case-control study of brain gliomas and occupational exposure to chemical carcinogens: the risk to farmers. Am J Epidemiol 1988;128:778-85.

62. Nomura A. Stomach. In: Schottenfeld D, Fraumeni JF Jr, ed. Cancer epidemiology and prevention. Philadelphia, PA: WB Saunders Co, 1982:624-37.

63. Hallenberg GR. Nitrates in Iowa groundwater. In: Itri FM, Wolfson LL, ed. Rural groundwater contamination. Chelsea, MA: Lewis Publications, 1987:23-68.

64. Alavanja MCR, Blair A, Masters MN. Cancer mortality in the US flour industry. J Natl Cancer Inst 1990;82: $840-8$.

65. Kneller RW, Gao Y, McLaughlin JK, Gao R, Blot WJ, Liu M, et al. Occupational risk factors for gastric cancer in Shangai, China. Am J Ind Med 1990;18:69-78.

66. Donham KJ, Berg JW, Sawin RS. Epidemiologic relationships of the bovine population and human leukemia in Iowa. Am J Epidemiol 1980;112:80-92.

67. Caldwell GG, Baumgartener L, Carter C. Seroepidemiologic testing in man for evidence of antibodies to feline leukemia virus and bovine leukemia virus. Bibl Haematol 1976;43:238-41.

68. Donham KJ, Van DerMaaten MJ, Miller JM, Kruse BC, Rubino MJ. Seroepidemiologic studies on the possible relationships of human and bovine leukemia: brief communication. J Natl Cancer Inst 1977;59:851-3.

69. Garrett NE, Stack HF, Waters MD. Evaluation of the genetic activity profiles of 65 pesticides. Mutat Res 1986; 168:301-25.

70. Thomas PT, Busse WW, Kerfvliet NI, Luster MI, Munson AE, Murray M, et al. Immunologic effects of pesticides. In: Baker SR, Wilkinson CR, ed. The effects of pesticides on human health. Princeton, NJ: Princeton Scientific Publ, 1990:261-95. (Advances in modern environmental toxicology XVIII.)

71. Newcombe DS. Immune surveillance, organophosphorus exposure and lymphomagenesis. Lancet 1992;339:53941.

72. Hoover R, Fraumeni JF Jr. Risk of cancer in renal transplant recipients. Lancet 1973;2:55-7.

73. Filipovich AH, Spector BD, Kersey J. Immunodeficiency in humans as a risk factor in the development of malignancy. Prev Med 1980;9:252-9.

74. Blohme I, Brynger $\mathbf{H}$. Malignant disease in renal transplant patients. Transplantation 1985;39:23-5.

75. Penn I. Immunosupression and skin cancer. Clin Plast Surg 1980;7:361.

76. Kinlen L, Doll R, Peto J. The incidence of tumors in human transplant recipients. Transplant Proc 1983;15: 1039-42.

77. Kolb HJ, Bender-Gotze C. Late complications after allogeneic bone marrow transplantation for leukaemia. Bone Marrow Transplant 1990;6:61-72.

78. Baker SR, Wilkinson CF, ed. Effects of pesticides on human health. Princeton, NJ: Princeton Scientific Publ, 1990. (Advances in modern environmental toxicology XVIII.)

79. Doll R, Peto R. The causes of cancer: quantitative estimates of avoidable risks of cancer in the United States today. J Natl Cancer Inst 1981;66:1191-308.

Received for publication: 10 February 1992 